\title{
DIVERSI SEBAGAI UPAYA ALTERNATIF PENYELESAIAN KASUS PIDANA ANAK PADA WILAYAH HUKUM POLRES MAROS
}

\author{
Diversion As An Alternative Measures For The Settlement of Criminal Cases of Children In The \\ Jurisdiction of The Polres Maros
}

\author{
Syarief Sikati ${ }^{1}$, Ruslan Renggong ${ }^{2}$, Baso Madiong ${ }^{2}$ \\ ${ }^{1}$ Kepolisian Resor Luwu Provinsi Sulawesi Selatan \\ ${ }^{2}$ Program Studi Ilmu Hukum Program Pascasarjana Universitas Bosowa
}

Email: syariefsikati@gmail.com

Diterima: 01 Agustus 2020/Disetujui: 05 Desember 2020

\begin{abstract}
ABSTRAK
Penelitian ini bertujuan untuk menganalisis diversi sebagai bentuk mediasi dan alternatif penyelesaian perkara tindak pidana anak pada Polres Maros. Penelitian ini dilakukan di Kabupaten Maros. Pendekatan penelitian menggunakan pendekatan yurdis normatif dan empiris. Data bersumber dari hasil wawancara dan studi pustaka. Hasil penelitian menunjukkan bahwa diversi merupakan alternatif penyelesaian perkara yang dilakukan anak walaupun tidak semua kasis yang dilakukan anak diselesaikan dengan diversi
\end{abstract}

Kata Kunci : Diversi, Penyelesaian Kasus, Pidana Anak, Polres, Maros

\begin{abstract}
This study aims to analyze diversion as a form of mediation and alternative settlement of criminal cases of children in the Maros Regional Police (Polres Maros). This research was conducted in Maros Regency. The research approach uses a normative and empirical judicial approach. Data sourced from interviews and literature study. The results showed that diversion was an alternative solution of crimes done by children even though not all cases made by children were resolved by diversion.
\end{abstract}

Keywords: Diversion, Case Resolution, Child Crime, Polres, Maros

\section{PENDAHULUAN}

Perkembangan zaman yang terjadi di masyarakat Indonesia terutama yang berkaitan dengan tatanan kehidupan bernegara tentunya tidak terlepas dari aturaaturan yang berlaku, terutama bila kita perbicara hukum pidana tentu tidak terlepas dari KUHP. Begitu juga dalam filosofi keadilan yang ingin ditegakkan dalam beberapa produk hukum dikenal dengan keadilan komunal mediasi dengan berlandaskan musyawarah untuk mufakat. Karena hukum akan menjadi sebagi obat terakhir yang dikenal dengan ultimum remedium.

Seyogyanya ancaman pidana merupakan suatu Ultimum Remedium, yang mengndung arti bahwa tidak meniadakan ancaman pidana. Terkhusus dengan penyelesaian perkara diluar persidangan tentunya diharapkan menjadi aternatif penyelesaian konflik antara pelaku dan korban setelah keduanya berdamai.

Berdasarkan UU yang berlaku penyelesaian perkara anak yang melakukan tindak pidana bisa dilakukan di luar pengadilan (diversi). Diversi ditegaskan dalam sistem peradilan anak dengan tujuan dapat menyelesaikan perkara pidana anak yang dilakukan di luar pengadilan.
Di bebepara daerah, termasuk di kabupaten Maros, proses penyelesian kasus yang melibatkan anak diproses seperti kasus orang dewasa melalui pengadilan. Hal ini menyebabkan preseden buruk bagi si anak dan akan melekat pada si anak sebagai narapidana yang akan mengakibatkan dampak negatif terhadap si anak dari sis mental dan jiwanya. Semestinya untuk menangani perkara anak harus dibedakan dengan orang dewasa. Yang menjadi dasar untuk ditempuh solusi alternatif karena anak dianggap masih labil, masa depannya masih panjang, dan anak ditempatkan sebagai aset bangasa, dan membutuhkan perlindungan.

Solusi yang bisa diberlakukan untuk memproses kasus anak adalah dengan yang kita kenal dengan sebutan diversi. Yaitu perlakuan mengalihkan kasus dari proses formal ke informal (Marlina, 2009) dan Wahyudi (2011).

Pengaturan yang jelas dan komprehensip mengenai perlindungan anak tertuang dalam UU no. 35 tahun 2014 yang bertujuan memberikan jaminan dan perlindungan hak anak untuk hidup, tumbuh, dan berkembang secara maksimal serta memperoleh perlindungan dari kekerasan dan diskriminatif (Muhdar dan Lisi, 2091). Diversi wajib 
diupayakan oleh penuntut umum anak jika kasusnya memenuhi syarat untuk dilakukan diversi (UU no, 11 tahun 2012).

Begitu pentingnya upaya diversi diterapkan di dalam sistem peradilan anak, sehingga pihak Polres Maros menerapkan diversi terhadap kasus yang memenuhi syarat untuk dilakukan diversi yang melibatkan antara anak dengan anak. Faktor-faktor yang menghambat peran pembimbing kemasyarakatan dalam penerapan restorative justice adalah kurangnya sumber daya manusia pembimbing kemasyarakatan, jangkauan wilayah kerja Bapas, kurangnya sarana dan prasarana, dukungan masyarakat dalam penerapan Restorative Justice, kurangnya partisipasi korban, orang tua dan pelaku, dan lambatnya koordinasi antar lembaga yang menangani masalah anak pelaku tindak pidana (Harliyanti, at.al, 2020)

Kasus yang menimpa anak di polres Maros tertinggi pada bulan Februari dan Maret 2019 yaitu masing masing sebanyak 6 kasus. Dan yang dilakukan diversi sebanyak 4 kasus yang terjadi dari Januari sampai dengan Desember 2019, Sebagaimana terlihat dalam tabel berikut ini.

Tabel 1

Data kasus pidana anak dari Januari sampai dengan Desember 2019

\begin{tabular}{|c|c|c|c|c|c|}
\hline No. & Bulan & SPDP & Tahap II & Diversi & Eksekusi \\
\hline 1. & Januari & 2 & 2 & 0 & 0 \\
\hline 2. & Februari & 6 & 3 & 0 & 2 \\
\hline 3. & Maret & 6 & 1 & 0 & 0 \\
\hline 4. & April & 2 & 4 & 1 & 0 \\
\hline 5. & Mei & 1 & 5 & 0 & 3 \\
\hline 6. & Juni & 3 & 2 & 1 & 2 \\
\hline 7. & Juli & 0 & 0 & 0 & 3 \\
\hline 8. & Agustus & 1 & 1 & 0 & 0 \\
\hline 9. & September & 1 & 1 & 2 & 5 \\
\hline 10 & Oktober & 0 & 2 & 0 & 0 \\
\hline 11. & November & 0 & 0 & 0 & 2 \\
\hline 12. & Desember & 1 & 1 & 0 & 1 \\
\hline \multicolumn{2}{|r|}{ Total } & 23 & 22 & 4 & 10 \\
\hline
\end{tabular}

Sumber: Data sekunder penelitian (2020)

Mengingat begitu rendahnya penyelesaian perkara yang menimpa anak melalui diversi di kabupaten Maros, yaitu 4 kasus saja atau sekitar $17 \%$ yang penyelesaiannya lewat diversi. Untuk itu, maka penelitian ini dimaksudkan untuk menganalisis Diversi sebagai bentuk mediasi dan alternatif penyelesaian perkara tindak pidana anak.

\section{METODE}

Pendekatan penelitian menggunakan pendekatan yurdis normatif dan empiris. Data bersumber dari hasil wawancara dan studi pustaka. Informan/Narasumber sebanyak 6 orang, terdiri dari Kapores Maros, Kanit Reskrim, anak yang berkasus, dan orang tuanya masing-masing. Analisis menggunakan analisis kualitatif dengan cara menguraikan data dalam bentuk kalimat yang akan diinterpretasikan untuk memperoleh suatu kesimpulan. Kemudian dilakukan penarikan kesimpulan secara induktif, yaitu menguraikan halhal yang bersifat khusus lalu menarik kesimpulan yang bersifat umum guna menjawab permasalahan yang diajukan.

\section{HASIL DAN PEMBAHASAN}

\subsection{Gambaran Kasus}

a. Kasus Pidana 1 (Permohonan Diversi Ditolak)

Kasus pidana yang melibatkan anak pada Polres Maros adalah seorang naak yang bernama Saiful Afsaril yang lahir di Maros, 1 September 1998, seorang pelajar. Dalam amar putusan disebutkan bahwa dalam laporan penyidik disebutkan antara anak dengan pihak lain dari pembimbing kemasyarakatan anaka, orang tua terlapor, penasihat hukum, kepala lingkungan VIII Kassi Kebo, ketua RT serta kepala satua reserse Narkotika Resort Maros, telah tercapai kesepakatan diversi sebagai mana dalam surat kesepakatan diversi atas nama Saiful Afsaril.

Berdasarkan ketentuan pasal 7 ayat (2) UU No. 11 Tahun 2012 pada pokoknya disebutkan diversi dilaksanakan terhadap tindak pidana dengan ancaman pidana penjara di bawah 7 tahun dan bukan kejahatan yang berulang.

Dalam analisis yuridis, berdasarkan fakta dan bukti yang telah disita berupa saat dilakukan penangkapan ditemukan uang sejumlah Rp. 400.000,- yang merupakan hasil penjualan narkotika, maka tersangka "Saiful" dapat disangkakan dengan pelanggaran pasal 114 ayat (1) Subs pasal 112 ayat (1) lebih subs. Pasal 127 ayat (1) Undang-undang RI No. 32 Tahun 2009 Tentang Narkotika.

Dalam upaya diversi yang dilakukan, pengadilan berpendapat tindak penyidikan melakukan diversi untuk kasus ini tidak memenuhi ketentuan yang disangkakan karena tindakan yang dilakukan adalah narkotika yang diancam 12 tahun.

Dalam proses diversi, pengadilan tidak hanya berpedoman pada angka-angka pada pasal yang disebutkan penyidik tetapi lebih pada subtansi perkara yang diuraikan dalam resume serta dalam peraturan MA RI Tahun 2014 tentang pedoman pelaksanaan diversi. Dalam peraturan tersebut diversi tidak diperuntukkan terhadap pindana serius. Maka pada kasus afrisa, ditolak karena tidak sesuai dengan peraturan perundang-undang tentang peraturan diversi.

b. Kasus Pidana 2 (Permohonan Diversi Dikabulkan)

Kasus pidana yang melibatkan anak yang masih berstatus pelajar bernama Muhammad Risal Rifaldi lahir di Makassar, 9 April 2003. Pada hari kamis, 27 Juni 2019, berlokasi di ruang mediasi PN maros, dihadapan Divo Ardianto, S.H., MH seorang fasilitator diversi, bersama orangorang yang terkait dalam perkara nomor: 2/pid.sus.anak/2019/Pn. Mrs. Akhirnya mencapai kesepakatan yang isinya antara lain sebagai berikut:

1) Bahwa tersangka mengaku sangat menyesal dengan perbuatan yang telah dilakukan.

2) Karena perilaku yang telah diperbuat, maka tersangka meminta maaf kepada korban dalam hal ini Muh. Khalil Foad.

3) Tersangka berjanji tidak mengulang perbuatannya lagi.

4) Tersangka bersedia memberikan ganti rugi sebesar Rp. 500.000 ,-

5) Pihak terkait sepakat untuk melakukan penyelesaian perkara dengan prinsip kekeluargaan.

6) Kedua orang tua pihak masih sanggup untuk mendidik, merawat dan membesarkan anaknya.

7) Kesepakatan ini dibuat tanpa unsur pengaruh dari manapun.

\subsection{Bentuk mediasi pada Polres Maros}

Perlindungan terhadap anak merupakan amanat konstitusi dimana anak berhak untuk hidup, tumbuh, dan 
berkembang dan mendapat perlindungan yang layak (UUD 1945: Pasal 28 B Ayat 2).

Sebagai aset bangsa dan generasi penerus perjuangan bangsa peranannya sangat strategis. Internasional menyadari hal ini dengan menghadirkan konvensi yang menempatkan anak sebagai manusia yag wajib dilindungi hak-haknya.

Penyimpangan perilaku anak dalam melakukan pelanggaran hukum merupakan permasalahan yang dihadapi bangsa ini sekaligus menjadi tantangan dalam menyelesaikan kasus yang menimpa anak. Banyak anak yang karena keadaan ekonomi keluarganya sehingga terpaksa melakukan pelanggaran, atau si anak tidak punya kesempatan tumbuh secara normal, baik mental, fisik maupun sosial yang sebenarnya merugikan buat dirinya sendiri. Oleh karena itu, untuk menangani kejahatan anak, maka orang-orang yang ada disekelilingnya, baik itu orang tuanya sendiri atau masyarakat sekitarnya, atau aparat penegak hukum seharusnya melakukan pencegahan, dan ketika kejahatan itu terlanjur terjadi maka penegakkan hukum seharusnya lebih diarahkan pada pembinaan dengan memberikan pendidikan dan pemahaman dalam upaya perkembangan si anak itu sendiri sehingga disini diperlukan aparat penegak hukum dalam menerapkan hukum buat si anak harus tetap memperhatikan dan mengadakan perlindungan hukum untuk si anak.

Proses peradilan bagi anak harus berpegang pada undang-undang perlindungan anak. Zai dan Siregar (2011), menegaskan bahwa proses pemeriksaan yang dilakukan oleh aparat penegak hukum dilakukan dengan tetap mementingkan hak anak atau memilih cara yang paling cocok untuk kesejahteraan anak. Penjatuhan pidana anak (delinkuen) akan mempengaruhi kondisi jiwa anak (Hadisuprapto, 2003) dan Arief (1994). Sehingga mediasi penal bisa digunakan dimana metode ini melibatkan berbagai pihak. Walaupun tergolong baru, memakai jalan mediasi penal sebagai alternatif peradilan anak namun ini menjadi salah satu alternatif untuk menjawab segala tantangan terhadap kasus anak. Tentu penerapannya harus dilakukan pada semua proses pemeriksaan, agar mengurangi dampak negatif keterlibatan anak dalam proses peradilan tersebut. Hal lain yang harus dapat perhatian adalah kategori kenakalan si anak. Dengan demikian kejahatan dapat dikelompokkan menjadi kejahatan tingkat ringan, sedang, dan berat.

Berdasarkan kategori tersebut yang bisa dilakukan diversi hanya terhadap kejahatan tingkat ringan dan sedang, sedangkan kejahatan berat prosesnya tidak dapat ditempuh proses diversi.

Terhadap anak yang harus di bawa ke persidangan karena melakukan perbuatan pidana tetap dikategorikan sama dengan perbuatan pidana yang dilakukan orang dewasa, hanya saja pelakunya tetap harus dibedakan. Cara membedakan ini yang harus dipahami oleh petugas yang menangani kasus semacam ini. Tujuannya adalah untuk melindungi dan menghormati hak asasi pelaku supaya cara penanganannya lebih jelas dan tidak diperlakukan sewenang-wenang dengan tidak wajar.

Konsepsi perlindungan anak tidak hanya sekedar perlindungan atas jiwa dan raganya, akan tetapi semua hak serta kepentingan si anak untuk tumbuh wajar, baik tumbuh secara jasmani, rohani maupun dari sisi sosialnya agar nantinya bisa tumbuh menjadi dewasa yang dapat berkarya (Soetodjo. 2006). Dalam penanganan kasus anak, yang jauh lebih penting adalah menghindari cap atau stigma jelek karena ini akan terbawa terus sampai dia tumbuh menjadi dewasa sekalipun si anak sudah tidak melakukan kejahatan lagi.

Kenyataan bahwa proses peradilan anak saat ini cenderung merugikan perkembangan jiwa si anak. Kecenderungan itu dikarenakan masih lemahnya pengaturan secara subtansial terhadap perlindungan anak, kurang profesinalnya penegak hukum dalam penanganan anak ditambah kuranya sarana dan prasarana untuk anak sewaktu menjalani proses pemeriksaan dan adjudikasi menjadi faktor yang dapat merugikan atau mengganggu perkembangan anak Hadisuprapto (2003: 73).

Berkaitan dengan hal itu, seorang informan dari Unit PPA Polres Maros berinisial SR mengatakan bahwa, dalam menangani masalah anak di lakukan dengan jalan memberikan bimbingan setelah penangkapan dilakukan. Ini agar anak bisa faham dan tidak melakukan kejahatan lagi. Namun terhadap anak yang mengulangi perbuatannya baru dilakukan langkah tegas. Ini dilakukan agar si anak dapat menyadari dan bertanggung jawab terhadap perbuatannya. Yang menyebabkan anak berhadapan dengan hukum dikategorikan dalam dua kategori, yaitu status offender dan juvenile delinguency. Status offender adalah kategori kenakalan anak yang jika perbuatan itu dilakukan orang dewasa bukan merupakan kejahatan, sedangkan juvenile delinquency adalah perilaku kenakalan anak yang kalau perbuatan itu dilakukan orang dewasa termasuk kategori kejahatan.

Proses hukum terhadap anak biasanya dimasukan dalam sistem peradilan pidana terpadu, yaitu mengutamakan pemenuhan dan perlindungan hak-hak anak. Persidangannyapun tertutup dan hakimnya tunggal. Dimana semua yang teribat dala persidangan tidak menggunakan pakaian dinas atau toga dengan menggunakan pendekatan bahwa anak dianggap belum mengerti atas apa yang dia perbuat dan dapat dibina atau diberi pemahaman akan kesalahan mereka.

Dari hasil riset Lembaga Advokasi Anak diketahui bahwa terhadap kasus anak diperlakukan buruk bahkan lebih buruk dalam beberapa kasus. Banyak anak mengaku diperlakukan kasar sewaktu diperiksa polisi. Kekerasan tersebut berupa kekerasan fisik, bahkan ada sampai mengarah ke pelecehan dengan ditelanjangi dan sebagainya.

Point penting yang ada dalam pasal 64 UUPA yang tidak terpenuhi oleh penagak hukum yaitu pemantauan dan pencatatan atas perkembangan anak, perlindungan dari media. Perlindungan ini dianggap penting bagi perkembangan secara psikologi bagi si anak.

\subsection{Alternatif Penyelesaian Perkara Tindak Pidana Anak}

Pengalihan proses peradilan anak ke proses di luar pengadilan, inilah yang disebut diversi. UU telah mengamanatkan bahwa dalam proses penyidikan, penuntutan, dan pemeriksaan perkara anak wajib diupayakan diversi. Namun demikian, diversi dapat dilakukan dalam hal tindak ancaman pidananya di bawah 7 tahun, bukan pengulangan kejahatan dan yang melakukan kejahatan adalah anak yang berusia 12 tahun ke atas.

Proses diversi dilakukan dengan tetap memperhatikan kepentingan-kepentingan anak. Hal-hal yang harus dipertimbangkan (Dalam Pasal 9 ayat 1) yaitu: Kategori tindak pidana, Usia Anak, riwayat kemasyarakatan dari Bapas, dan lingkungan keluarga dan masyarakat. Hasil dari diversi harus disetujui oleh korban sendiri atau keluarganya serta kesediaan anak dan keluarganya, terkecuali untuk tindak 
pidana yang berupa pelanggaran, sipatnya ringan, pidana tanpa korban, dan nilai kerugian korban tidak melebihi nilai UMP setempat.

Prinsip dalam pelaksanaan diversi yaitu tindakan persuasif untuk untuk memperbaiki kesalahan. Sehingga diharapkan dengan diversi tidak ada lagi tindakan penyiksaan, pemaksaan ataupun tindak kekerasan dalam proses-proses peradilan anak. Proses diversi diharapkan Tidak terjadi lagi tindak kekerasan dan dapat menjadi kesempatan kepada anak untuk memperbaiki dirinya.

\section{KESIMPULAN DAN SARAN}

Hasil penelitian dan pembahasan dapat disimpulkan bahwa terhadap dari 23 kasus pidana yang melibatkan anak di kabupaten Masor hanya 4 kasus saja yang diupayakan diselesaikan melalui diversi. Ini berarti bahwa pelaksanaan diversi belum dianggap salah satu proses mediasi penal terbaik untuk menanggulangi masalah anak pelaku tindak pidana. Pelaksanaan diversi sebaiknya dilakukan yang sesuai dengan ide dan pengaturannya berdasarkan aturan yang berlaku dan sesuai instrumen-instrumen yang diakui secara internasional.

\section{DAFTAR PUSTAKA}

Arief, B. N. (1994). Beberapa Aspek Pengembangan Ilmu Hukum Pidana (Menyongsong Generasi Baru Hukum Pidana Indonesia). Pidato Pengukuhan Guru Besar Fakultas Hukum Undip, Semarang, 25.

Hadisuprapto, P. (2003). Menemukan Upaya Mengatasi Tindak Kekerasan.

Harliyanti, H., Renggong, R., \& Haris, A. H. (2021) Efektivitas Peran Pembimbing Kemasyarakatan Dalam Penerapan Restorative Justice Terhadap Anak Pelaku Tindak Pidana Pada Balai Pemasyarakatan Kelas I Makassar. Indonesian Journal of Legality of Law, 2(2), 88-93. https://doi.org/10.35965/ijlf.v2i2.420

Marlina, P. P. A. D. I. (2009). Pengembangan konsep diversi dan Restorative Justice. Refika Aditama, Bandung.

Muhdar, M., \& Lisi, I. Z. (2018). Konstruksi Hukum Diversi Pada Tahap Pelaksanaan Peradilan Anak. Mulawarman Law Review, 111-123.

Soetodjo, W. (2006). Hukum pidana anak.

Undang-undang Nomor 11 Tahun 2012 tentang Sistem Peradilan Pidana Anak

Wahyudi, S. (2011). Implementasi ide diversi dalam pembaruan sistem peradilan pidana anak di Indonesia. Genta Pub..

Zai, A., \& Siregar, T. (2011). Perlindungan Hukum terhadap Anak yang Berhadapan dengan Hukum dalam Sistem Peradilan Anak (Studi pada Wilayah Hukum Polres Nias). Jurnal Mercatoria, 4(2), 99-116. 